\title{
EUS - Fine- Needle Aspiration Biopsy (FNAB) in the Diagnosis of Pancreatic Adenocarcinoma: A Review
}

\author{
ALEXANDRA KALOGERAKI ${ }^{1}$, GEORGIOS Z. PAPADAKIS ${ }^{2}$, DIMITRIOS TAMIOLAKIS ${ }^{1}$, \\ ILIANA KARVELA-KALOGERAKI ${ }^{1}$, MIHAILOS KARVELAS-KALOGERAKIS ${ }^{1}$, JOHN SEGREDAKIS ${ }^{1}$, \\ MICHAEL PAPADAKIS ${ }^{1}$, ELENI MOUSTOU $^{1}$, GALATEIA DATSERI $^{1}$, MARIA TZARDI $^{1}$ \\ ${ }^{1}$ Department of Pathology-Cytopathology, Medical School, University of Crete, University Hospital, Heraklion, Crete, Greece \\ ${ }^{2}$ Department of Radiology and Imaging Sciences, National Institutes of Health (NIH), Clinical Center (CC), Bethesda, MD, USA
}

\begin{abstract}
Solid masses of the pancreas represent a variety of benign and malignant neoplasms of the exocrine and endocrine tissues of the pancreas. A tissue diagnosis is often required to direct therapy in the face of uncertain diagnosis or if the patient is not a surgical candidate either due to advanced disease or comorbidities. Endoscopic ultrasound (EUS) is a relatively new technology that employs endoscopy and high-frequency ultrasound (US). EUS involves imaging of the pancreatic head and the uncinate from the duodenum and imaging of the body and tail from the stomach. It has been shown to be a highly sensitive method for the detection of pancreatic masses. It is superior to extracorporeal US and computed tomographic (CT) scans, especially when the pancreatic tumor is smaller than $2-3 \mathrm{~cm}$. Although EUS is highly sensitive in detecting pancreatic solid masses, its ability to differentiate between inflammatory masses and malignant disease is limited. Endoscopic retrograde cholangiopancreatography (ERCP) brushing, CT-guided biopsies, and transabdominal ultrasound (US) have been the standard nonsurgical methods for obtaining a tissue diagnosis of pancreatic lesions, but a substantial false-negative rate has been reported. Transabdominal US-guided fine-needle aspiration biopsy (US-FNAB) has been used for tissue diagnosis in patients with suspected pancreatic carcinoma. It has been shown to be highly specific, with no false-positive diagnoses. With the advent of curvilinear echoendoscopes, transgastric and transduodenal EUS-FNAB of the pancreas have become a reality EUS with FNAB has revolutionized the ability to diagnose and stage cancers of the gastrointestinal tract and assess the pancreas. Gastrointestinal cancers can be looked at with EUS and their depth of penetration into the intestinal wall can be determined. Any suspicious appearing lymph nodes can be biopsied using EUS/FNAB. The pancreas is another organ that is well visualized with EUS. Abnormalities such as tumors and cysts of the pancreas can be carefully evaluated using EUS and then biopsied with FNAB. There are many new applications of EUS using FNAB. Researchers are looking to deliver chemotherapeutics into small pancreatic cancers and cysts. Nerve blocks using EUS/FNAB to inject numbing medicines into the celiac ganglia, a major nerve cluster, are now routinely performed in patients with pain due to pancreatic cancer. The aim of this study is to perform a review of the literature regarding the usefulness of EUS/FNAB in the diagnosis of pancreatic adenocarcinoma.
\end{abstract}

Key words: Pancreas, Pancreatic ductal adenocarcinoma, FNAB, cytology, immunocytochemistry.

\section{INTRODUCTION}

EUS-with FNAB has become an important technique of gastroenterologists for the diagnosis of pancreatic adenocarcinoma before chemotherapy and / or surgery. EUS alone is limited in its ability to discriminate between malignant and benign processes. EUS-FNAB, with its ability to obtain a tissue diagnosis, has increased the accuracy of EUS in the diagnosis of pancreatic adenocarcinoma. The sensitivity, specificity, and accuracy of EUS-FNAB for pancreatic lesions range from $64 \%$ to $94 \%, 71 \%$ to $100 \%$ and $78 \%$ to $95 \%$ respectively [1-6] Thirtythree studies published between 1997-2009 with 4984 patients were included, as the pool sensitivity for malignant cytology was $85 \%$ and pooled specificity was $98 \%$. If atypical and suspicious cytology results were included to determine true neoplasms, the sensitivity increased to $91 \%$. The diagnostic accuracy of EUS-FNAB was enhanced in prospective, multicenter studies and demonstrates that EUS-FNAB is a highly accurate diagnostic test for solid neoplasms of the pancreas [7]. Pancreatic adenocarcinoma is a significant cause of mortality and represents a major healthcare burden worldwide. Pancreatic adenocarcinomas are the fifth leading cause of cancer related death in the USA [8] and the incidence of these tumors continues to rise. The survival rate of patients with these tumors is extremely poor, with an overall 5-year survival rate of less than 5\% [9], making it one of the biggest "cancer killers". This poor survival rate largely reflects the late presentation of patients with pancreatic adenocarcinoma and limited treatment 
modalities for advanced disease, the average survival time after diagnosis is only 6 months [10]. Therefore, early and accurate diagnosis is vital for improving the efficacy of therapeutic intervention. Adenocarcinoma was more likely to be present in the head of the pancreas, have lymph node and vascular involvement, as well as evidence of pancreatic duct and common bile duct obstruction.

Surgical resection remains the only potentially curative treatment for pancreatic adenocarcinoma, and yet is still an extremely complex intervention with significant periprocedural morbidity and mortality [11]. Accurate preoperative diagnosis of patients presenting with a pancreatic mass lesion is vital to preventing unnecessary procedures in those with benign disease and to correctly stage individuals with malignant lesions, enabling accurate identification of those who may benefit from surgery [12].

The regional anatomy of the pancreas is complex, making procurement of cytologic samples historically difficult without exploratory laparotomy. Traditionally, computed tomography (CT) or endoscopic ultrasound-guided FNA (EUS-FNA) has been used to obtain biopsies of the pancreas. However, not all lesions are accessible due to surrounding organs and vasculature. Additionally, these techniques are associated with a risk of peritoneal dissemination of cancer cells and have a falsenegative rate of up to $20 \%[13,14]$. Endoscopic retrograde cholangiopancreatography (ERPC) brush cytology has a false-negative rate of at least $30 \%$ [15].

EUS was developed in the 1980s to improve the imaging of the pancreas. Traditional transabdominal ultrasound imaging of the pancreas is hampered by intervening bowel gas, bone and fat. By placing a high-frequency transducer directly with the stomach or duodenum lumen, EUS can obtain a detailed image of the pancreas that has a higher resolution than $\mathrm{CT}$ scan or magnetic resonance imaging, but with a much narrower field of view. These high-resolution images allow for identification of lesions as 2-3 mm and involvement of adjacent vascular structures [16].

This review specifically addresses the role of EUS-FNAB in the diagnosis and confirmation of pancreatic adenocarcinoma.

\section{REVIEW}

Ductal adenocarcinoma of the pancreas (Papanicolaou stain), (Figure 1) and its variants account for more than $90 \%$ of pancreatic malignnancies. The cytological criteria for the diagnosis of this tumor have been published by Mitchell and Carney in 1985 [17]. They focused on threedimensional cellular fragments, nuclear enlargement, and nuclear membrane irregularity. Following this publication, several modified cytologic criteria based on those of Mitchell and Carney were reported. Cohen et al. [18] identified anisonucleosis, nuclear molding and large nuclei as the significant cytological features for the diagnosis of pancreatic adenocarcinoma.

Robins et al. [19] were the first to distinguish major (overlapping nuclei/ crowded groups, nuclear contour irregularity, and chromatic clearing and/or clumping) and minor criteria (single epithelial cells, necrosis, mitosis and nuclear enlargement) for pancreatic adenocarcinoma.

According to Robins et al. the sensitivity and specificity for diagnostic pancreatic adenocarcinoma are $100 \%$ when two or more major criteria or one major and three minor criteria are identified. Several other authors also considered single epithelial cells, necrosis, mitosis and prominent nucleoli as significant cytologic features [20-22].

Before the published criteria of Mitchell and Carney, Brits and Franz [23] studied a small series of FNAB of pancreas and suggested that pale nodular nuclei were a possible specific marker for pancreatic adenocarcinoma. Pale nodular nuclei were described as homogeneously hypochromatic nuclear chromatin, nuclear membrane irregularity with deep folds, and one or more large eosinophilic nucleoli. Pale nodular nuclei are not diagnostic of pancreatic adenocarcinoma because they are also present in benign pancreatic aspirate specimens as well as in the other types of malignancy, such as melanoma and lung carcinomas.

The cytological diagnosis of poorly differentiated (PDA) or even moderately differentiated adenocarcinoma (MDA) is usually straightforward. The problematic diagnostic cases generally involve well differentiated adenocarcinoma WDA [24].

It is important to recognize that anisonucleosis, nuclear crowding/overlapping, and nuclear membrane irregularity may occur focally in WDA, whereas nuclear enlargement usually involves the entire group of neoplastic ductal epithelial cells. It is also imperative to emphasize that none of those criteria, when present singly, is pathognomonic for WDA. Nuclear enlargement and focal crowding/ overlapping are commonly observed in certain reactive conditions, especially pancreatitis. However, marked anisonucleosis/variation in nuclear size greater than four times in the same epithelial group and nuclear membrane irregularities (deep notch, deep groove, popcorn, or rasinoid) are nearly always absent in reactive conditions. Many tumor- 
associated markers have been reported to be useful in the diagnosis of pancreatic adenocarcinoma [2541]. A recent study [42] investigates the utility of 26 different immunohistochemical markers cytokeratin panel (CAM 5.2, CK7, CK20, CK17, CK19), mucin panel (MUC1, MUC2, MUC4, MUC5AC, MUC6), tumor protein p53, tumor suppressor gene DPC4/SMA D4, CDX2 (a recently cloned homeobox gene that encodes an intestine-specific transcription factor, expressed in the nuclei of epithelial cells throughout the intestine, from duodenum to rectum), the Von Hippel-Lindau tumor suppressor protein (PVHL), the calcium binding protein S100
$\mathrm{P}$, the Insulin-like growth factor II mRNA-binding protein 3 (IMP-3), mapsin, mesothelin, claudin 4, claudin 18, annexin A8, fascin, Prostate stem cell antigen (PSCA), MOC31 antibody, also known as Epithelial Specific Antigen/Ep-CAM, carcinoembryonic antigen (CEA) and carbohydrate antigen 19-9, also called cancer antigen 19-9 or sialylated Lewis (a) antigen (CA19-9) (Figures 2,3) in the diagnosis of ductal adenocarcinoma of the pancreas. The results of that study demonstrate that PVHL, mapsin, S100P and IMP-3 constitute the most effective panel of markers in the distinction of pancreatic adenocarcinoma from benign/reactive pancreatic ducts.

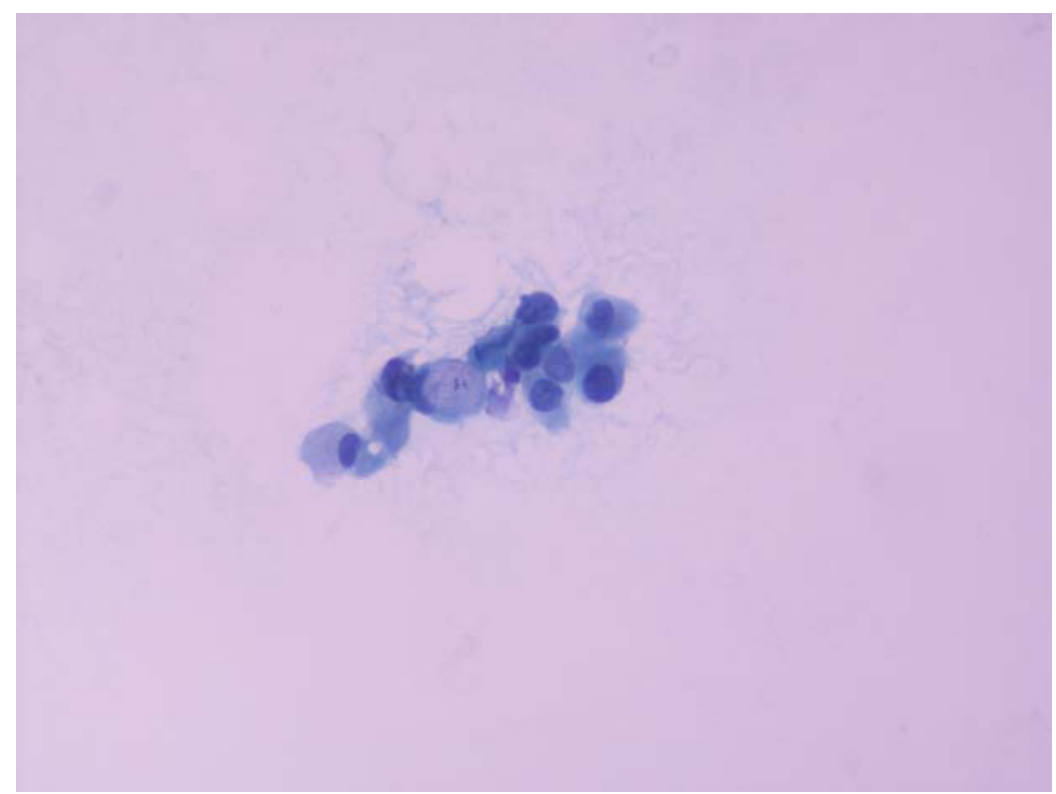

Figure 1. Ductal adenocarcinoma of the pancreas. FNAB. Poorly cohesive group of tumor cells with mild anisonucleosis, pale nuclei. nuclear contour irregularity, and chromatic clearing or clumping Papanicolaou stain X400.

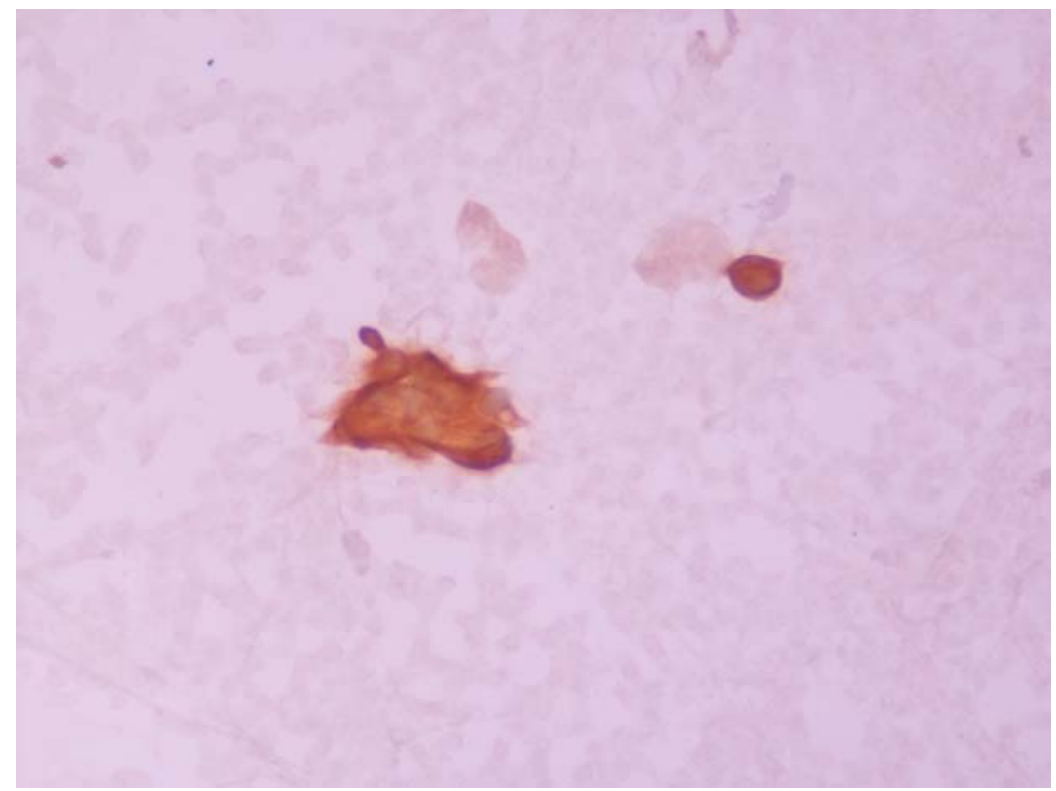

Figure 2. Ductal adenocarcinoma of the pancreas. FNAB. A small cluster of malignant ductal cells CK7 positive. CK7 immunostain X400. 


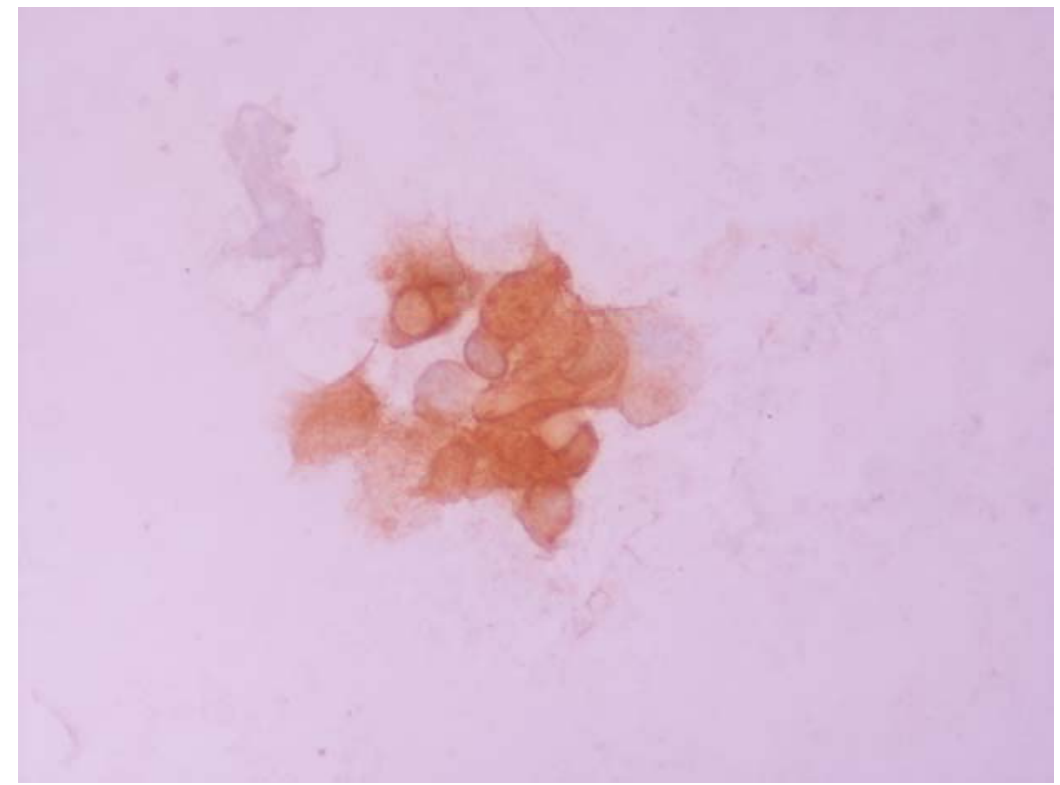

Figure 3. Ductal adenocarcinoma of the pancreas. FNAB. A cohesive cluster of malignant ductal cells CEA positive. CEA immunostain X400.

Another study [43] on EUS-FNAB in cases of pancreatic adenocarcinoma demonstrates that among five antibodies, S100P reveals the best diagnostic characters showing $90 \%$ of sensitivity and $67 \%$ of specificity. Fascin shows high specificity (92\%) but low sensitivity (38\%). Mesothelin has a moderate sensitivity (74\%) and low specificity (33\%), PSCA and 14-3-3 sigma show high sensitivity but zero specificity.

To achieve higher diagnostic efficacy, some investigators have used molecular analysis of EUSFNA samples. Especially, some reports suggested that the presence of K-ras gene mutations in tissue obtained by EUS-FNA improved the accuracy of the diagnosis.

Takahashi et al. reported that K-ras point mutations were found in $74 \%$ of pancreatic cancers and $0 \%$ of focal pancreatitis lesions [44]. They also mentioned that analysis for the K-ras point mutation in specimens obtained by EUS-guided FNA might enhance diagnostic accuracy in indeterminate cases. Hosoda et al. suggested they could achieve a diagnosis from EUS-FNA specimens of invasive ductal carcinomas, endocrine tumors and acinar cell tumors by using immunostaining for CK7, CDX2, chromogranin A and synaptophysin with $\mathrm{K}$-ras mutation analysis [45]. Deng et al. reported the usefulness of immunostaining of S100P [46] and Giorgadze et al. reported a mucin panel comprising all four antibodies (MUC1, MUC2, MUC5AC and MUC6) might be helpful in differentiating normal/reactive duodenal and gastric epithelium from neoplastic pancreatic tissue [47]. Those reports might help to improve the efficacy of EUS-FNA for diagnosis of solid pancreatic masses.

Molecular analysis has widened the role of EUS-FNA of solid pancreatic masses into treatment fields. Referring to the correlation between deoxycytidine kinase (dCK) activity and gemcitabine sensitivity [48], Ashida et al. reported dCK mRNA expression in EUS-FNA biopsy specimens might be a predictor for response to gemcitabine in patients with unresectable cancer [49]. Although there was no correlation between the expression levels of human equilibrative nucleoside transporter-1 (hENT-1) and gemcitabine efficacy in Ashida et al.'s study, Giovannetti et al. suggested hENT-1 expression might be a possible prognostic factor for chemosensitivity of pancreatic cancer to gemcitabine [50]. In addition, Fujita et al. reported that quantitative analysis of not only dCK and hENT-1, but also RRM1 and RRM2 mRNA levels in microdissected neoplastic cells from EUS-FNA specimens might be useful in predicting the gemcitabine sensitivity of patients with pancreatic ductal adenocarcinoma [51]. Through these further investigations, EUSFNA might lead the way to 'tailor made therapies'.

EUS-FNAB shows the highest sensitivity $(95 \%)$ and specificity (91\%). In different studies retrieved from PUBMED database since 2003, the sensitivity, specificity, positive predictive value, negative predictive value and accuracy of EUSFNA for pancreatic solid masses were reported to be $78-95 \%, 75-100 \%, 98-100 \%, 46-80 \%$ and $78-$ $95 \%$, respectively. There was no improvement of the efficacy of EUS-FNA even though new equipment and procedures have been developed. Of course, 
one of the reasons is that EUS-FNA has been carried out in many different hospitals and institutes all over the world, at times by relatively inexperienced operators. But the results have been excellent, that is to say, EUS-FNA for diagnosis of solid pancreatic masses is 'a nearly perfected procedure' [52].

\section{CONCLUSION}

We reviewed the role of EUS-FNA for the diagnosis of pancreatic adenocarcinoma and EUS-
FNA should be carried out with an on-site pathological evaluation. EUS-FNAB cytomorphology is superior to any one of the immunohistochemical markers used. In the diagnosis of pancreatic adenocarcinoma if there is enough cytomorphological evidence for the diagnosis of malignancy, immunohistochemical markers are not required.

To reach a higher level of accuracy, it might be necessary to explore different diagnostic dimensions. Because on-site cytopathologic evaluation improves the diagnostic yields of EUS-FNA, more effort should be made to include this assessment during EUS-FNA procedures.

\begin{abstract}
Masele solide pancreatice reprezintă o varietate de tumori maligne şi benigne ale țesutului enodcrin şi exocrin pancreatic. Un diagnostic bioptic este de multe ori necesar în fața unui diagnostic incert sau dacă pacientul nu poate fi operat datorită comorbidităților sau a bolii avansate. Ecografia endoscopică (EUS) este o metodă dezvoltată relativ recent. EUS presupune evaluarea capului de pancreas şi a lobului uncincat atunci când sonda este plasată duodenal şi a cozii şi corpului pancreatic atunci când sonda este plasată gastric. EUS s-a demonstrat a fi o metodă foarte sensibilă pentru detecția maselor pancreatice, fiind superioară ecografiei abdominale şi a CT-ului mai ales când masele pancreatice au mai puțin de 2-3 cm. Totuşi capacitatea de diferențiere dintre inflamație şi tumori este scăzută. Colangiografia pancreatică retrogradă endoscopică (ERCP) însoțită de periaj, biopsiile ghidate prin CT sau ecografie sunt tehnicile standard utilizate pentru obținerea de țesut pancreatic în vederea diagnosticului maselor pancreatice. Aspirația pe ac fin ghidată ecografic (US-FNAB) s-a dovedit a fi înalt specifică, fiind o tehnică care a îmbunătățit capacitatea de a diagnostica şi a evalua malignitățile tractului digestiv şi ale pancreasului. În plus, orice ganglion limfatic suspect poate fi biopsiat. Această metodă pare să deschidă noi orizonturi intrucât se evaluează posibilitatea de a administra țintit chimioterapeutice direct în masele tumorale. Tehnica este deja utilă pentru blocarea selectivă a nervilor ganglionilor celiaci folosită în tratamentul paleativ al durerii la pacienții cu cancer pancreatic. Obiectivul acestui articol a fost de a evalua literatura de specialitate privind diagnosticul adenocarcinomului pancreatic.
\end{abstract}

Correspondence to: Alexandra Kalogeraki ,MD, $\mathrm{PhD}$

University of Crete, Medical Faculty, PO Box 1393, Heraklion 71110, Crete, Greece

E-mail: kalogerakimed@yahoo.gr

\title{
REFERENCES
}

1. RAUT CP, GRAU AM, STAERKEL GA, et al. Diagnostic accuracy of endoscopic ultrasound-guided fine-needle aspiration in patients with presumed pancreatic cancer. J Gastrointest Surg. 2003; 7(1):118-28.

2. ELOUBEIDI MA, CHEN VK, ISAM A, ELTOUM IA, et al. Endoscopic ultrasound-guided fine needle aspiration biopsy of patients with suspected pancreatic cancer: diagnostic accuracy and acute and 30-day complications. The American Journal of Gastroenterology .2003; 98:2663-8.

3. HAREWOOD G, WIERSEMA MJ. Endosonography-guided fine needle aspiration biopsy in the evaluation of pancreatic masses. The American Journal of Gastroenterology.2002; 97: 1386-91.

4. YLAGAN LR, EDMUNDOWICZ S, KASAL K, et al. Endoscopic ultrasound guided fine-needle aspiration cytology of pancreatic carcinoma. A 3-year experience and review of the literature. Cancer Cytopathology. 2002; 96(6):362-9.

5. FRITSCHER-RAVENS A, IZBICKI JB, SRIRAM VJP, et al. Endosonography-guided, fine-needle aspiration cytology extending the indication for organ-preserving pancreatic surgery. The American Journal of Gastroenterology.2000; 95:2255-60. 
6. AFIFY AM, AL-KHAFAJI BM, KIM B, SCHEIMAN JM et al. Endoscopic ultrasound-guided fine needle aspiration of the pancreas. Diagnostic utility and accuracy. Acta Cytologica. 2003: 47(3):341-8.

7. MICHAEL JONATHAN HEWITT, MCPHAIL, MRCP, LUCIA POSSAMAI, AMEET DHAR, PANAGIOTIS VLAVIANOS,, KEVIN J. MONAHAN. EUS-guided FNA for diagnosis of solid pancreatic neoplasms: a meta-analysis. Gastrointestinal Endoscopy.2012; 75(2):319-31.

8. DEMAY RM. The art and science of cytopathology: pancreas. Chicago: ASCP Press. 1996: 1059-69.

9. NIEDERHUBER JE, MURRAY F. BRENNAN, HERMAN R. MENCK. The national cancer data base report on pancreatic cancer. Cancer. 1995; 76 (9): 1671-77.

10. BECKINGHAM IJ. ABC of liver, pancreas and gallbladder, $1^{\text {st }}$ ed. London: BMJ: 2001.

11. GREENBLATT DY, KELLY KJ, RAJAMANICKAM V. Preoperative factors predict perioperative morbidity and mortality after pancreaticoduodenectomy. Annals of Surgical Oncology. 2011; 18(8):2126-35.

12. NOH KW, WALLACE MB. Endoscopic ultrasound-guided fine-needle aspiration in the diagnosis and staging of pancreatic adenocarcinoma. MedGenMed. 2005; 7(2): 15- 19.

13. BRET PM, VIVIANE NICOLET V, LABADIE M. Percutaneous fine-needle aspiration biopsy of the pancreas. Diagnostic Cytopathology.1986; 2(3):221-7.

14. BRANDT KR, CHARBONEAU JW, STEPHENS DH, et al. CT- and US-guided biopsy of the pancreas. Radiology. 1993; 187: 99-104.

15. LEE JG, LEUNG J. Tissue sampling at ERCP in suspected pancreatic cancer. Gastrointestinal Endoscopy Clinics of North America. 1998; 8(1):221-35.

16. PAQUIN SC, GARIÉPY G, LEPANTO L, et al. A first report of tumor seeding because of EUS-guided FNA of a pancreatic adenocarcinoma. Gastrointest Endosc. 2005 Apr; 61(4):610-1.

17. MITCHELL ML, CARNEY CN. Cytologic criteria for the diagnosis of pancreatic carcinoma. American Journal of Clinical Pathology. 1985; 83(2):171-6.

18. COHEN MB, EGERTER DP, HOLLY EA, AHN DK, MILLER TR. Pancreatic adenocarcinoma: Regression analysis to identify improved cytologic criteria. Diagnostic Cytopathology.1991; 7(4):341-5.

19. ROBINS DB, KATZ RL, EVANS DB, ATKINSON EN, GREEN L. Fine needle aspiration of the pancreas. In quest of accuracy. Acta Cytologica. 1995; 39(1):1-10.

20. FEKETE PS, NUNEZ C, DEBORAH A. PITLIK DA. Fine-needle aspiration biopsy of the pancreas: A study of 61 cases. Diagnostic Cytopathology. 1986; 2(4):301-6.

21. AL-KAISI N, SIEGLER EE. Fine needle aspiration cytology of the pancreas. Acta Cytologica. 1989; 33(2):145-52.

22. KOCJAN G, RODE J, LEES WR. Percutaneous fine needle aspiration cytology of the pancreas: advantages and pitfalls. J Clin Pathol 1989; 42:341-7.

23. BRITS CJ, FRANZ RC. Pale nodular nuclei-diagnostic of adenocarcinoma of the pancreas? Acta Cytologica. 1976; 20(5):462-8.

24. LIN F, STAERKEL GM. Cytologic criteria for well differentiated adenocarcinoma of the pancreas in fine-needle aspiration biopsy specimens. Cancer Cytopathology. 2003; 99(1):44-50.

25. LIN F, JIANHUI S, HAIYAN L, et al. Diagnostic utility of S100P and von Hippel-Lindau Gene Product (pVHL) in pancreatic adenocarcinoma - with implication of their roles in early tumorigenesis. American Journal of Surgical Pathology. 2008; 32(1):78-91.

26. LEVY M, LIN F, XU H, DHALL D, BETSY O. SPAULDING BO, WANG HL. S100P, von Hippel-Lindau gene product and IMP3 serve as a useful immunohistochemical panel in the diagnosis of adenocarcinoma on endoscopic bile duct biopsy. Human Pathology. 2010; 41(9):1210-1219.

27. ZHAO H, MANDICH D, RICHARD W. CARTUN RW, LIGATO S. Expression of $K$ homology domain containing protein overexpressed in cancer in pancreatic FNA for diagnosing adenocarcinoma of pancreas. Diagnostic Cytopathology.2007; 35(11):700-4.

28. KYOKO K, NOBUYUKI O, SEISHIRO M, MASASHI S, MANABU T, TOSHIO M. Expression of the tumor suppressor gene maspin and its significance in intraductal papillary mucinous neoplasms of the pancreas. Hepatobiliary Pancreat Dis Int. 2008; 7(1):86-90.

29. AGARWAL B, LUDWIG, OJ, BRIAN T. COLLINS BT, CORTESE C. Immunostaining as an adjunct to cytology for diagnosis of pancreatic adenocarcinoma. Clinical Gastroenterology and Hepatology. 2008; 6(12):1425-1431.

30. MCCARTHY DM, MAITRA A; ARGANI P, et al. Novel markers of pancreatic adenocarcinoma in fine-needle aspiration: Mesothelin and prostate stem cell antigen labeling increases accuracy in cytologically borderline cases. Applied Immunohistochemistry \& Molecular Morphology. 2003; 11(3):238-43.

31. HASSAN R, LASZIK ZG, MEGAN LERNER M, RAFFELD M, POSTIER R, BRACKETT D. Mesothelin is overexpressed in pancreaticobiliary adenocarcinomas but not in normal pancreas and chronic pancreatitis. American Journal of Clinical Pathology.2005; 124: 838-845.

32. KARANJAWALA ZE, ILLEI PB, ASHFAQ R, et al. New markers of pancreatic cancer identified through differential gene expression analyses: Claudin 18 and Annexin A8. Am J Surg Pathol. 2008; 32(2): 188-196.

33. DE LOTT LB, MORRISON C, SUSTER S, COHN DE, FRANKEL WL. CDX2 is a useful marker of intestinal-type differentiation: a tissue microarray-based study of 629 tumors from various sites. Arch Pathol Lab Med. 2005; 129(9):1100-5.

34. GOLDSTEIN NS, BASSI D. Cytokeratins 7, 17, and 20 reactivity in pancreatic and ampulla of vater adenocarcinomas. Percentage of positivity and distribution is affected by the cut-point threshold. Am J Clin Pathol. 2001; 115(5):695-702.

35. CHU PG, SCHWARZ RE, LAU, SK, YEN Y, WEISS L. Immunohistochemical staining in the diagnosis of pancreatobiliary and ampulla of vater adenocarcinoma: Application of CDX2, CK17, MUC1, and MUC2. American Journal of Surgical Pathology. 2005; 29(3):359-367. 
36. LAU SK, PRAKASH S, GELLER SA, ALSABEH R. Comparative immunohistochemical profile of hepatocellular carcinoma, cholangiocarcinoma, and metastatic adenocarcinoma. Human Pathology 2002; 33(12):1175-1181.

37. KOHJI NAGATA, MICHIKO HORINOUCHI, MIYUKI SAITOU, et al. Mucin expression profile in pancreatic cancer and the precursor lesions. Journal of Hepato-Biliary-Pancreatic Surgery.2007; 14(3):243-254.

38. NIRAG JHALA, DARSHANA JHALA, SELWYN M. VICKERS, et al. Biomarkers in diagnosis of pancreatic carcinoma in fine-needle aspirates: A translational research application. American Journal of Clinical Pathology. 2006: 126:572-9.

39. TAMAR A. GIORGADZE, HEATHER PETERMAN, ZUBAIR BALOCH, et al. Diagnostic utility of mucin profile in fineneedle aspiration specimens of the pancreas: An immunohistochemical study with surgical pathology correlation. Cancer Cytopathology. 2006; 108(3):186-197.

40. KOSARAC O, TAKEI H, ZHAI QJ, SCHWARTZ MR, MODY DR. S100P and XIAP expression in pancreatic ductal adenocarcinoma: Potential novel biomarkers as a diagnostic adjunct to fine needle aspiration cytology. Acta Cytologica 2011; 55: $142-148$.

41. WACHTER DL, SCHLABRAKOWSKI A, HOEGEL J, KRISTIANSEN G, HARTMANN A, RIENER MO. Diagnostic value of immunohistochemical IMP3 expression in core needle biopsies of pancreatic ductal adenocarcinoma. American Journal of Surgical Pathology. 2011; 35(6):873-877.

42. LIU H, SHI J, ANANDAN V, WANG HL, DIEHL D, BLANSFIELD J, GERHARD G, LIN F. Reevaluation and identification of the best immunohistochemical panel (pVHL, Maspin, S100P, IMP-3) for ductal adenocarcinoma of the pancreas. Arch Pathol Lab Med. 2012;136(6):601-9.

43. DANIEL C. DIM, FENG JIANG, QI QIU, TING, PETER DARWIN, WILLIAM H. RODGERS, HONG QI PENG. The usefulness of S100P, mesothelin, fascin, prostate stem cell antigen, and 14-3-3 sigma in diagnosing pancreatic adenocarcinoma in cytological specimens obtained by endoscopic ultrasound guided fine-needle aspiration. Diagnostic Cytopathology 2014; 42(3):193-9.

44. TAKAHASHI K, YAMAO K, OKUBO K et al. Differential diagnosis of pancreatic cancer and focal pancreatitis by using EUS-guided FNA. Gastrointest. Endosc. 2005; 61: 76-9.

45. HOSODA W, TAKAGI T, MIZUNO N et.al. Diagnostic approach to pancreatic tumor with the specimens of endoscopic ultrasound-guided fine needle aspiration. Pathol. Int. 2010; 60: 358-64.

46. DENG H, SHI J, WILKERSON M, FUPREE W, LIN F. Usefulness of S100P in diagnosis of adenocarcinoma of pancreas on fine needle aspiration biopsy specimens. Am. J. Clin. Pathol. 2008; 129: 81-8.

47. GIORGADZE TA, PETERMAN H, BALOCH ZW et al. Diagnostic utility of mucin profile in fine-needle aspiration specimens of the pancreas. Cancer Cytopathol. 2006; 108: 186-97.

48. KROEP JR, LOVES WJ, VAN DER WILT CL et al. Pretreatment deoxycytidine linase levels predict in vivo gemcitabine sensitivity. Mol. Cancer Ther. 2002; 1: 371-6.

49. ASHIDA R, NAKATA B, SHIGEKAWA M et al. Gemcitabine sensitivity-related mRNA expression in endoscopic ultrasoundguided fine-needle aspiration biopsy of unresectable pancreatic cancer. J. Exp. Clin. Cancer Res. 2009; 28: 83.

50. GIOVANNETTI E, DEL TACCA M, MEY V et al. Transcription analysis of human equilibrative nucleoside transporter-1 predicts survival in pancreas cancer patients treated with gemcitabine. Cancer Res. 2006; 66: 3928-35.

51. FUJTTA H, OHUCHIDA K, MIZUMOTO K et al. Gene expression levels as predictive markers of outcome in pancreatic cancer after gemcitabine-based adjuvant chemotherapy. Neoplasia 2010; 12: 807-10.

52. YOSHINAGA S, SUZUKI H, ODA I, SAITO Y. Role of endoscopic ultrasound-guided fine needle aspiration (EUS-FNA) for diagnosis of solid pancreatic masses. Dig Endosc. 2011; 23 Suppl 1:29-33.

Received March 30, 2015 